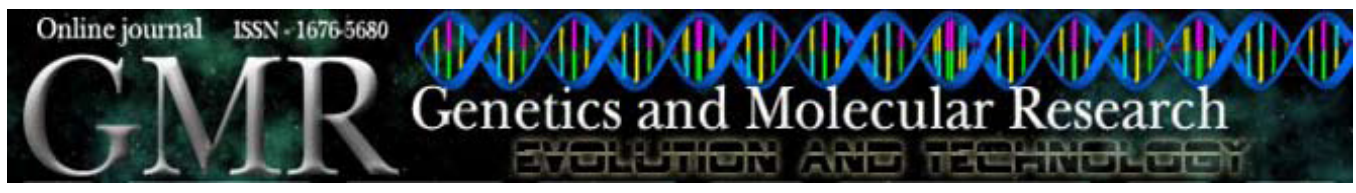

\title{
Lack of clastogenic/genotoxic effects of Baccharis dracunculifolia extract on Swiss mouse peripheral blood cells
}

\author{
N.S. Andrade 1 , F.F. Perazzo ${ }^{2}$ and E.L. Maistro ${ }^{3}$ \\ ${ }^{1}$ Laboratório de Genética, Universidade José do Rosário Vellano, \\ Alfenas, MG, Brasil \\ ${ }^{2}$ Laboratório de Pesquisa em Fármacos, Universidade Federal do Amapá, \\ Macapá, AP, Brasil \\ ${ }^{3}$ Departamento de Fonoaudiologia, Faculdade de Filosofia e Ciências, \\ Universidade Estadual Paulista, Marília, SP, Brasil \\ Corresponding author: E.L. Maistro \\ E-mail: edson.maistro@marilia.unesp.br
}

Genet. Mol. Res. 7 (4): 1414-1421 (2008)

Received October 14, 2008

Accepted October 23, 2008

Published December 23, 2008

\begin{abstract}
Baccharis dracunculifolia De Candole (DC) (Asteraceae) is indigenous throughout southeastern Latin America and is used by local people in traditional medicine. This plant is known to be the source of resin for the highly valued Brazilian green propolis. As no information is available on the safety of high doses of $B$. dracunculifolia extract, we evaluated the mutagenic potential of high doses of this plant extract in vivo on peripheral blood cells of Swiss mice using the comet assay and the micronucleus test. The extract was administered by gavage at doses of 1000, 1500 and $2000 \mathrm{mg} / \mathrm{kg}$ body weight. Peripheral blood cell samples were collected 4 and $24 \mathrm{~h}$ after treatment for the comet assay (genotoxicity assay), and at 48 and $72 \mathrm{~h}$ for the micronucleus test (clastogenicity assay). The $B$. dracunculifolia extract was devoid of clastogenic/genotoxic activity at all doses.
\end{abstract}

Key words: Baccharis dracunculifolia; Micronucleus test; Single cell gel electrophoresis; Mutagenicity assay 


\section{INTRODUCTION}

Phytotherapy is very popular worldwide and common mainly among adult women for a variety of health conditions (Lewith, 2000). While many herbal products are benign in nature, some of these compounds have potentially harmful side-effects: recent examples include ephedra use linked to cardiovascular problems (Andraws et al., 2005), the relationship between kava-kava consumption and hepatotoxicity (Ernst, 2002), and the Phyllantus orbicularis extract use and genotoxicity and cytotoxicity in Chinese hamster ovary (CHO) cells (Sánchez-Lamar et al., 2002). This has led to an increased concern for the possible threat to human health posed by exposure to phytochemicals and other chemicals.

Baccharis dracunculifolia DC (Asteraceae, local name in Brazil: Alecrim do campo and vassourinha) is a woody dioecious shrub (2-3 $\mathrm{m}$ in height) distributed throughout southern Brazil. Its leaf extracts have been used as an antipyretic, a stomachic, and a health tonic in Brazil (Menezes, 2005). Potent cytotoxic activity against leukemia cells and antiulcer activity have also been reported (Fukuda et al., 2006; Lemos et al., 2007; Massignani et al., 2008). It has been reported that this plant is a source of resin for Brazilian propolis (green propolis), because of the similarity of their chemical constituents (Park et al., 2004). In vitro toxicological studies of green propolis revealed that low concentrations show antimutagenicity and high concentrations show mutagenicity effects (Tavares et al., 2006). In vivo analysis confirmed that high doses produced mutagenic effects (Pereira et al., 2008).

The chemical composition of this plant has been well studied during the last years and the extract consists of a defined mixture of components, including baccharisketone, $p$-methoxythymol acetate, caryophyllene oxide, thymol, carvacrol, $p$-methoxythymol, 4-isopropyl2-methylphenol, spathulenol, $p$-cymene-2,3-diol, bisacumol, 2-methyl-6-(4'-methylphenyl)3-hepten-2-ol, 1 $\beta$-hydroxyeudesma-4(15),7-diene, cadinol, an oppositane type sesquiterpene, germacra-1(11),5(12),6(E)-trien-2-ol, a tricyclic sesquiterpene, 3,4,3',4'-tetra-hydroxy-5,5'diisopropyl-2,2'-dimethylbiphenyl, 3-acetoxy-4',5-dihydroxy-7-methoxyflavanone, and naringenin (Park et al., 2004; Fukuda et al., 2006).

Since $B$. dracunculifolia has been used for a long time in folk medicine and since high doses of green propolis produced genotoxicity in vivo, the present study was carried out to investigate the clastogenic/genotoxic potential of a hydroalcoholic extract of $B$. dracunculifolia on Swiss mouse peripheral blood cells, employing the micronucleus test and the single cell gel electrophoresis (SCGE) assay.

\section{MATERIAL AND METHODS}

\section{Plant material}

The leaves of B. dracunculifolia were collected in Alfenas town, Minas Gerais, Brazil, and identified by Prof. Dr. Fábio Ferreira Perazzo. Leaves (300 g) of B. dracunculifolia were air dried at $40^{\circ} \mathrm{C}$, powdered and extracted by maceration with water-ethanolic solvent (4 L, $90 \%$ ethanol) for 2 days. The macerate was filtered and concentrated under reduced pressure, furnishing $26.4 \mathrm{~g}$ ( $8.8 \%$ yield) of crude water-ethanolic extract. 


\section{Chemicals}

N-nitroso-N-ethylurea (ENU, Sigma, CAS No. 759-73-9) was used as the DNA damaging agent in the comet and micronucleus assay using Swiss mice, and was dissolved in phosphate buffer, $\mathrm{pH}$ 6. The other main chemicals were obtained from the following suppliers: normal melting point agarose (Cat. No. 15510-019: Invitrogen); low melting point agarose (Cat. No. 15517-014; Invitrogen); sodium salt $N$-lauroyl sarcosine (L-5125; Sigma), and ethylenediaminetetraacetic acid (EDTA, Merck).

\section{Animals and assay procedures}

Experiments were carried out in 12-week-old Swiss mice (Mus musculus), weighing 25-30 g. The animals were acquired from the animal house of the José do Rosário Vellano University (UNIFENAS), kept in polyethylene boxes $(\mathrm{N}=6)$, in a climate-controlled environment $\left(25 \pm 4^{\circ} \mathrm{C}, 55 \pm 5 \%\right.$ humidity) with a 12 -h light/dark cycle (7:00 am to 7:00 pm). Food (Labina - Purina) and water were available ad libitum. The mice were divided into experimental groups of six animals, with three females and three males in each group. B. dracunculifolia extract was administered in a single dose of $0.5 \mathrm{~mL}$ by gavage, at doses of 1000,1500 , and $2000 \mathrm{mg} / \mathrm{kg}$ body weight, chosen on the basis of our acute toxicity studies in mice, where toxic doses were higher than $2000 \mathrm{mg} / \mathrm{kg}$. The negative control group received distilled water. The positive control group, received $50 \mathrm{mg}$ ENU/kg. The comet assay was carried out using the method described by Speit and Hartmann (1999), which is based on the original study of Singh et al. (1988) and includes modifications introduced by Klaude et al. (1996) as well as additional modifications. Four and $24 \mathrm{~h}$ after the treatment, peripheral blood leukocytes from mice were obtained. A $10-\mu \mathrm{L}$ aliquot of the cells from each animal was mixed with $120 \mu \mathrm{L}$ $0.5 \%$ low melting point agarose at $37^{\circ} \mathrm{C}$, and rapidly spread onto microscope slides pre-coated with $1.5 \%$ normal melting point agarose. The slides were coverslipped and allowed to gel at $4^{\circ} \mathrm{C}$ for $20 \mathrm{~min}$. The coverslips were removed gently and the slides were then immersed in cold, freshly prepared lysing solution consisting of $89 \mathrm{~mL}$ of a stock solution $(2.5 \mathrm{M} \mathrm{NaCl}$, $100 \mathrm{mM}$ EDTA, $10 \mathrm{mM}$ Tris, $\mathrm{pH}$ set to 10.0 with $\sim 8 \mathrm{~g}$ solid $\mathrm{NaOH}, 890 \mathrm{~mL}$ distilled water and $1 \%$ sodium lauroyl sarcosine), plus $1 \mathrm{~mL}$ Triton X-100 (Merck) and $10 \mathrm{~mL}$ DMSO. Protected from light, the slides were allowed to stand at $4^{\circ} \mathrm{C}$ for $1 \mathrm{~h}$ and then placed in the gel box, positioned at the anode end, and left in a high $\mathrm{pH}(>13)$ electrophoresis buffer $(300 \mathrm{mM} \mathrm{NaOH}$ per $1 \mathrm{mM}$ EDTA, prepared from a stock solution of $10 \mathrm{~N} \mathrm{NaOH}$ and $200 \mathrm{mM}$ EDTA, pH 10.0 ,) at $4^{\circ} \mathrm{C}$ for $20 \mathrm{~min}$ before electrophoresis to allow the DNA to unwind. The electrophoresis run was performed in an ice bath $\left(4^{\circ} \mathrm{C}\right)$ for $20 \mathrm{~min}$ at $25 \mathrm{~V}$ and $300 \mathrm{~mA}$. The slides were then submerged in a neutralization buffer $(0.4 \mathrm{M}$ Tris- $\mathrm{HCl}, \mathrm{pH} 7.5)$ for $15 \mathrm{~min}$, dried at room temperature and fixed in $100 \%$ ethyl alcohol for $10 \mathrm{~min}$. The slides were dried and stored at least overnight before staining. For the staining process, slides were briefly rinsed in distilled water, covered with $30 \mu \mathrm{L} 1 \mathrm{X}$ ethidium bromide staining solution prepared from a 10X stock $(200 \mu \mathrm{g} / \mathrm{mL})$ and covered with a coverslip. The material was evaluated immediately at $400 \mathrm{X}$ magnification, using a fluorescence microscope (Olympus) with a 515-560-nm excitation filter and a $590-\mathrm{nm}$ barrier emission filter. For the micronucleus assay, peripheral blood from the same animals used in the comet assay was collected from the orbital vein 48 and $72 \mathrm{~h}$ after the treatment, and slides of blood smears were then prepared. All slides were coded, fixed with 
methanol and stained with Giemsa solution (MacGregor et al., 1980). Four thousand polychromatic erythrocytes from each Swiss mouse (2000 cells from $48 \mathrm{~h}$ blood sample and 2000 cells from $72 \mathrm{~h}$ blood sample) were scored. For each blood sample (48 and $72 \mathrm{~h}$ ), 1000 cells were analyzed per animal to determine the polychromatic/normochromatic erythrocyte ratio. The animals utilized in this study were sacrificed by cervical dislocation. The Animal Bioethics Committee of the UNIFENAS, Brazil, approved the present study in February 2005 (protocol number 03A/2005), in accordance with the Brazil's federal laws on animal care.

\section{Scoring procedures and data evaluation (comet assay)}

The extent and distribution of DNA damage indicated by the SCGE assay was evaluated by examining at least 100 randomly selected and non-overlapping cells on the slides per animal. These cells were scored visually, according to tail size into four classes, as follows: i) class 0 , no tail; ii) class 1 , tail shorter than the diameter of the head (nucleus); iii) class 2, tail length 1 to 2 times the diameter of the head, and iv) class 3, tail longer than 2 times the diameter of the head. Comets with no heads and images with nearly all DNA in the tail, or with a very wide tail, were excluded from the evaluation because they probably represent dead cells (Hartmann and Speit, 1997). The total score for 100 comets was obtained by multiplying the number of cells in each class by the damage class, ranging from 0 (all undamaged) to 300 (all maximally damaged).

\section{Statistical analysis}

The data obtained for micronucleus and SCGE assays were submitted to one-way analysis of variance (ANOVA) and the Tukey multiple comparison test (Sokal and Rohlf, 1995), using the GraphPad Instat ${ }^{\circledR}$ software (version 3.01). The differences were considered to be statistically significant at $\mathrm{P}<0.05$.

\section{RESULTS AND DISCUSSION}

It is necessary early in the development of unknown products and chemicals to determine the potential mutagenic effects. A balance between therapeutic versus toxicological effects of the compound is important when determining its applicability as a pharmacological drug.

Micronuclei appear in cells due to chromosomal damage during the last mitosis and they are the reliable indicators of mutagenicity of exogenous agents (Salamone et al., 1980). Although there are several routes by which micronuclei may be produced, the acentric chromosomes generated due to the chromosomal damage are the leading candidates for their formation (Salamone et al., 1980; Mitchell and Combes, 1997). When the acentrics form micronuclei, they result in structures that are smaller in size than the ones produced by entire chromosomes (Heddle et al., 1991).

Table 1 shows the micronucleus test results obtained for female and male Swiss mice treated with $B$. dracunculifolia extract: the number of micronucleated polychromatic erythrocytes (MNPCE) for each animal and means, for untreated controls and treated animals.

The results obtained did not show statistically significant increase in the average number of micronucleated polychromatic erythrocytes at the three doses of the plant extract tested. Com- 
parisons between different dose groups showed no significant differences between MNPCE mean values (Tukey test, $\mathrm{P}>0.05$ ). These results showed that $B$. dracunculifolia extract does not act as an aneugen in the mice peripheral blood cells and does not produce chromosomal fragments, that in either case leads to micronuclei.

Table 1. Micronucleated polychromatic erythrocytes (MNPCE) observed in peripheral blood cells of female (F) and male (M) Swiss mice treated with a Baccharis dracunculifolia extract, and respective controls.

\begin{tabular}{|c|c|c|c|c|c|c|c|c|c|}
\hline \multirow[t]{2}{*}{ Treatments } & \multirow[t]{2}{*}{$\begin{array}{l}\text { Time of blood } \\
\text { collection }\end{array}$} & \multicolumn{6}{|c|}{$\begin{array}{c}\text { Number of MNPCE } \\
\text { per animal }\end{array}$} & \multirow[t]{2}{*}{$\begin{array}{c}\text { MNPCE } \\
(\text { Mean } \pm \text { SD) }\end{array}$} & \multirow[t]{2}{*}{$\begin{array}{c}\mathrm{PCE} / \mathrm{NCE} \\
(\mathrm{Mean} \pm \mathrm{SD})\end{array}$} \\
\hline & & $\mathrm{F}_{1}$ & $\mathrm{~F}_{2}$ & $\mathrm{~F}_{3}$ & $\mathrm{M}_{1}$ & $\mathrm{M}_{2}$ & $\mathrm{M}_{3}$ & & \\
\hline \multirow{2}{*}{$\begin{array}{l}\text { Control } \\
\text { (water) }\end{array}$} & $48 \mathrm{~h}$ & 0 & 1 & 2 & 0 & 0 & 2 & $0.83 \pm 0.98$ & $0.84 \pm 0.07$ \\
\hline & $72 \mathrm{~h}$ & 1 & 3 & 0 & 0 & 0 & 1 & $0.83 \pm 1.17$ & $0.88 \pm 0.05$ \\
\hline \multirow{2}{*}{$\begin{array}{l}\text { B. dracunculifolia } \\
(1000 \mathrm{mg} / \mathrm{kg})\end{array}$} & $48 \mathrm{~h}$ & 1 & 1 & 3 & 1 & 3 & 1 & $1.66 \pm 1.03$ & $0.80 \pm 0.08$ \\
\hline & $72 \mathrm{~h}$ & 1 & 3 & 3 & 1 & 2 & 1 & $1.83 \pm 0.98$ & $0.82 \pm 0.03$ \\
\hline \multirow{2}{*}{$\begin{array}{l}\text { B. dracunculifolia } \\
(1500 \mathrm{mg} / \mathrm{kg})\end{array}$} & $48 \mathrm{~h}$ & 1 & 0 & 0 & 0 & 1 & 0 & $0.33 \pm 0.52$ & $0.84 \pm 0.07$ \\
\hline & $72 \mathrm{~h}$ & 1 & 2 & 0 & 1 & 0 & 0 & $0.66 \pm 0.82$ & $0.79 \pm 0.09$ \\
\hline \multirow{2}{*}{$\begin{array}{l}\text { B. dracunculifolia } \\
(2000 \mathrm{mg} / \mathrm{kg})\end{array}$} & $48 \mathrm{~h}$ & 1 & 1 & 1 & 0 & 2 & 1 & $1.00 \pm 0.63$ & $0.79 \pm 0.10$ \\
\hline & $72 \mathrm{~h}$ & 0 & 1 & 0 & 1 & 1 & 0 & $0.50 \pm 0.55$ & $0.76 \pm 0.11$ \\
\hline (N-nitroso-N-ethylurea) & $48 \mathrm{~h}$ & 25 & 23 & 13 & 33 & 32 & 18 & $24.0 \pm 7.8^{*}$ & $0.74 \pm 0.06$ \\
\hline$(50 \mathrm{mg} / \mathrm{kg})$ & $72 \mathrm{~h}$ & 35 & 32 & 11 & 35 & 35 & 17 & $27.5 \pm 10.7 *$ & $0.72 \pm 0.10$ \\
\hline
\end{tabular}

*Significantly different from negative control $(\mathrm{P}<0.001)$. Two thousand cells were analyzed per animal, for a total of 12,000 cells per group. $\mathrm{PCE}=$ polychromatic erythrocytes; $\mathrm{NCE}=$ normochromatic erythrocytes.

Table 1 also shows the ratio between the average number of polychromatic erythrocytes (PCE), in relation to normochromatic erythrocytes (NCE) in 1000 randomly cells analyzed for each animal. The PCE/NCE ratio was not significantly different from the negative control group indicating that the $B$. dracunculifolia extract does not show cytotoxic properties in Swiss mouse peripheral blood cells at any of the doses tested (Tukey test, $\mathrm{P}>0.05$ ).

The comet assay is an attractive test in genetic toxicology because it involves: a potentially high-throughput screening assay; mechanistic studies to distinguish between genotoxicityversus cytotoxicity-induced chromosomal damage, and mechanistic in vivo studies to distinguish between genotoxic versus non-genotoxic carcinogens (Tice et al., 2000). This assay was used in the present study to determine DNA damage measured as strand breaks and alkali-labile sites in blood peripheral leukocytes of albino Swiss mice. Tables 2 and 3 show the effects of 4- and 24-h treatments, respectively, with the extract on DNA migration in peripheral blood leukocytes from Swiss mice on the comet assay. As expected, the ENU agent used as positive control led to some fragmentation and migration of the fragments in the SCGE assay peripheral blood cells. No significant effects on DNA migration were found at the three $B$. dracunculifolia extract concentrations tested in leukocytes. When exposed to the test extract, most cells examined on the slides were undamaged (class 0), a few cells showed minor damage (class 1 ) and a very few showed a large amount of damage (classes 2 and 3). Furthermore, there was no significant difference in DNA migration among the three extract concentrations tested. 


\begin{tabular}{|c|c|c|c|c|c|c|c|}
\hline \multirow[t]{2}{*}{ Treatments } & \multirow[t]{2}{*}{ Animals } & \multirow[t]{2}{*}{ Total $^{1}$} & \multicolumn{4}{|c|}{ Comet class } & \multirow[t]{2}{*}{ Scores } \\
\hline & & & 0 & 1 & 2 & 3 & \\
\hline \multirow[t]{7}{*}{ Control } & $\mathrm{F}_{1}$ & 5 & 95 & 5 & 0 & 0 & 5 \\
\hline & $\mathrm{F}_{2}$ & 5 & 95 & 5 & 0 & 0 & 5 \\
\hline & $\mathrm{F}_{3}$ & 6 & 94 & 6 & 0 & 0 & 6 \\
\hline & $M_{1}$ & 6 & 94 & 6 & 0 & 0 & 6 \\
\hline & $\mathrm{M}_{2}$ & 4 & 96 & 4 & 0 & 0 & 4 \\
\hline & $\mathrm{M}_{3}$ & 10 & 90 & 10 & 0 & 0 & 10 \\
\hline & Mean \pm SD & $6.0 \pm 2.09$ & & & & & $6.0 \pm 2.0$ \\
\hline \multirow{7}{*}{$\begin{array}{l}\text { B. dracunculifolia extract } \\
(1000 \mathrm{mg} / \mathrm{kg})\end{array}$} & $\mathrm{F}_{1}$ & 11 & 89 & 11 & 0 & 0 & 11 \\
\hline & $\mathrm{F}_{2}$ & 9 & 91 & 9 & 0 & 0 & 9 \\
\hline & $\mathrm{F}_{3}^{2}$ & 26 & 74 & 25 & 1 & 0 & 27 \\
\hline & $M_{1}$ & 14 & 86 & 14 & 0 & 0 & 14 \\
\hline & $\mathrm{M}_{2}$ & 28 & 72 & 27 & 1 & 0 & 29 \\
\hline & $\mathrm{M}_{3}$ & 36 & 64 & 31 & 2 & 3 & 44 \\
\hline & Mean \pm SD & $20.6 \pm 10.8$ & & & & & $22.3 \pm 13.5$ \\
\hline \multirow{7}{*}{$\begin{array}{l}\text { B. dracunculifolia extract } \\
(1500 \mathrm{mg} / \mathrm{kg})\end{array}$} & $\mathrm{F}_{1}$ & 13 & 87 & 12 & 1 & 0 & 14 \\
\hline & $\mathrm{F}_{2}$ & 29 & 71 & 23 & 2 & 4 & 39 \\
\hline & $\mathrm{F}_{3}$ & 2 & 98 & 2 & 0 & 0 & 2 \\
\hline & $M_{1}$ & 39 & 61 & 37 & 0 & 2 & 43 \\
\hline & $\mathrm{M}_{2}$ & 8 & 92 & 8 & 0 & 0 & 8 \\
\hline & $\mathrm{M}_{3}$ & 29 & 71 & 27 & 2 & 0 & 31 \\
\hline & Mean \pm SD & $20.0 \pm 14.4$ & & & & & $22.8 \pm 17.1$ \\
\hline \multirow{7}{*}{$\begin{array}{l}\text { B. dracunculifolia extract } \\
(2000 \mathrm{mg} / \mathrm{kg})\end{array}$} & $\mathrm{F}_{1}$ & 3 & 97 & 3 & 0 & 0 & 3 \\
\hline & $\mathrm{F}_{2}$ & 2 & 98 & 2 & 0 & 0 & 2 \\
\hline & $\mathrm{F}_{3}^{2}$ & 2 & 98 & 2 & 0 & 0 & 2 \\
\hline & $M_{1}$ & 6 & 94 & 6 & 0 & 0 & 6 \\
\hline & $\mathrm{M}_{2}$ & 6 & 94 & 6 & 0 & 0 & 6 \\
\hline & $\mathrm{M}_{3}$ & 5 & 95 & 4 & 0 & 1 & 7 \\
\hline & Mean \pm SD & $4.0 \pm 1.89$ & & & & & $4.33 \pm 2.2$ \\
\hline \multirow{7}{*}{$\begin{array}{l}\text { N-nitroso-N-ethylurea } \\
(50 \mathrm{mg} / \mathrm{kg})\end{array}$} & $\mathrm{F}_{1}$ & 86 & 14 & 59 & 21 & 6 & 119 \\
\hline & $\mathrm{F}_{2}$ & 92 & 8 & 62 & 24 & 6 & 128 \\
\hline & $\mathrm{F}_{3}$ & 28 & 72 & 27 & 1 & 0 & 29 \\
\hline & $M_{1}$ & 97 & 3 & 60 & 25 & 12 & 146 \\
\hline & $\mathrm{M}_{2}$ & 93 & 7 & 78 & 7 & 8 & 116 \\
\hline & $\mathrm{M}_{3}$ & 60 & 40 & 42 & 9 & 9 & 87 \\
\hline & Mean \pm SD & $76.0 \pm 27.0^{*}$ & & & & & $104.1 \pm 41.5^{*}$ \\
\hline
\end{tabular}

*Significantly different from the negative control $(\mathrm{P}<0.001) .{ }^{1}$ Total number of damaged cells $($ classes $1+2+3)$.

B. dracunculifolia is a source of resin for Brazilian propolis (green propolis) (Park et al., 2004). Tavares et al. (2006) observed in CHO cells that green propolis is genotoxic at high concentrations, while at lower concentrations it displays antigenotoxic effects, indicating the characteristic of a "Janus" compound. Similar results were obtained by Munari et al. (2008) analysing B. dracunculifolia extract in CHO cells by chromosomal aberration assays. Lima (2007) observed that different fractions of green propolis produced increase in the mutagenicity of the methyl methane sulfonate in $\mathrm{CHO}$ cells, and in the $\mathrm{H}_{2} \mathrm{O}_{2}$ mutagenicity in $\mathrm{CHO}$ and $\mathrm{HepG} 2$ cells. These same fractions produced chemopreventive activity against the mutagens diethyl-nitrosamine and 4-nitroquinoline 1-oxide. Pereira et al. (2008) observed that the acute consumption of high doses of green propolis produced some mutagenic effects on blood cells of mice, confirming in vitro results obtained by Tavares et al. (2006). On the other hand, an ethyl acetate extract of $B$. dracunculifolia showed no 
Table 3. DNA migration in the comet assay for the assessment of genotoxicity of Baccharis dracunculifolia extract in peripheral blood leukocytes from female (F) and male (M) Swiss mice collected $24 \mathrm{~h}$ after treatment in vivo.

\begin{tabular}{|c|c|c|c|c|c|c|c|}
\hline \multirow[t]{2}{*}{ Treatments } & \multirow[t]{2}{*}{ Animals } & \multirow[t]{2}{*}{ Total $^{1}$} & \multicolumn{4}{|c|}{ Comet class } & \multirow[t]{2}{*}{ Scores } \\
\hline & & & 0 & 1 & 2 & 3 & \\
\hline \multirow{7}{*}{ Control } & $\mathrm{F}_{1}$ & 12 & 88 & 11 & 0 & 1 & 14 \\
\hline & $\mathrm{F}_{2}$ & 8 & 92 & 8 & 0 & 0 & 8 \\
\hline & $\mathrm{F}_{3}^{2}$ & 16 & 84 & 16 & 0 & 0 & 16 \\
\hline & $\mathrm{M}_{1}$ & 7 & 93 & 7 & 0 & 0 & 7 \\
\hline & $\mathrm{M}_{2}$ & 24 & 76 & 24 & 0 & 0 & 24 \\
\hline & $\mathrm{M}_{3}^{2}$ & 10 & 90 & 10 & 0 & 0 & 10 \\
\hline & Mean \pm SD & $12.8 \pm 6.32$ & & & & & $13.1 \pm 6.33$ \\
\hline \multirow{7}{*}{$\begin{array}{l}\text { B. dracunculifolia extract } \\
(1000 \mathrm{mg} / \mathrm{kg})\end{array}$} & $\mathrm{F}_{1}$ & 5 & 95 & 5 & 0 & 0 & 5 \\
\hline & $\mathrm{F}_{2}$ & 19 & 81 & 18 & 1 & 0 & 20 \\
\hline & $\mathrm{F}_{3}$ & 18 & 82 & 17 & 1 & 0 & 19 \\
\hline & $\mathrm{M}_{1}^{3}$ & 17 & 83 & 15 & 2 & 0 & 19 \\
\hline & $\mathrm{M}_{2}$ & 29 & 71 & 29 & 0 & 0 & 29 \\
\hline & $\mathrm{M}_{3}$ & 21 & 79 & 20 & 0 & 1 & 23 \\
\hline & Mean \pm SD & $18.1 \pm 7.75$ & & & & & $19.1 \pm 7.91$ \\
\hline \multirow{7}{*}{$\begin{array}{l}\text { B. dracunculifolia extract } \\
(1500 \mathrm{mg} / \mathrm{kg})\end{array}$} & $\mathrm{F}_{1}$ & 26 & 74 & 23 & 1 & 2 & 31 \\
\hline & $\mathrm{F}_{2}$ & 15 & 85 & 14 & 0 & 1 & 17 \\
\hline & $\mathrm{F}_{3}$ & 7 & 93 & 7 & 0 & 0 & 7 \\
\hline & $\mathrm{M}_{1}^{3}$ & 13 & 87 & 10 & 2 & 1 & 17 \\
\hline & $\mathrm{M}_{2}$ & 8 & 92 & 18 & 0 & 0 & 18 \\
\hline & $\mathrm{M}_{3}^{2}$ & 26 & 74 & 21 & 2 & 3 & 34 \\
\hline & Mean \pm SD & $15.8 \pm 8.42$ & & & & & $20.6 \pm 10.0$ \\
\hline \multirow{7}{*}{$\begin{array}{l}\text { B. dracunculifolia extract } \\
(2000 \mathrm{mg} / \mathrm{kg})\end{array}$} & $\mathrm{F}_{1}$ & 11 & 89 & 11 & 0 & 0 & 11 \\
\hline & $\mathrm{F}_{2}$ & 16 & 84 & 16 & 0 & 0 & 16 \\
\hline & $\mathrm{F}_{3}^{2}$ & 10 & 90 & 10 & 0 & 0 & 10 \\
\hline & $M_{1}$ & 9 & 91 & 9 & 0 & 0 & 9 \\
\hline & $\mathrm{M}_{2}$ & 16 & 84 & 16 & 0 & 0 & 16 \\
\hline & $\mathrm{M}_{3}^{2}$ & 25 & 75 & 25 & 0 & 0 & 25 \\
\hline & Mean \pm SD & $14.5 \pm 5.95$ & & & & & $14.5 \pm 5.95$ \\
\hline \multirow{7}{*}{$\begin{array}{l}\text { N-nitroso-N-ethylurea } \\
(50 \mathrm{mg} / \mathrm{kg})\end{array}$} & $\mathrm{F}_{1}$ & 43 & 26 & 72 & 2 & 0 & 76 \\
\hline & $\mathrm{F}_{2}$ & 56 & 47 & 53 & 0 & 0 & 53 \\
\hline & $\mathrm{F}_{3}$ & 61 & 79 & 21 & 0 & 0 & 21 \\
\hline & $\mathrm{M}_{1}^{3}$ & 52 & 47 & 52 & 1 & 0 & 54 \\
\hline & $\mathrm{M}_{2}$ & 41 & 59 & 41 & 0 & 0 & 41 \\
\hline & $\mathrm{M}_{3}^{2}$ & 43 & 57 & 38 & 3 & 2 & 50 \\
\hline & Mean \pm SD & $49.3 \pm 8.21^{*}$ & & & & & $49.1 \pm 17.9^{*}$ \\
\hline
\end{tabular}

*Significantly different from the negative control $(\mathrm{P}<0.001) .{ }^{1}$ Total number of damaged cells $($ classes $1+2+3)$.

mutagenic effect on the rat erythrocyte micronucleus test (Resende et al., 2007). The same authors even observed that the extract causes a significant reduction in the frequency of polychromatic erythrocytes with micronuclei induced by doxorubicin, probable due to the antioxidant properties of the flavonoids present in this plant. In conclusion, the results obtained in the present study show that the mixed compounds present in crude water-ethanol extract of $B$. dracunculifolia did not induce any clastogenic/genotoxic response in blood cells of mice, when administered at high, single doses, confirming the results of Resende et al. (2007).

\section{ACKNOWLEDGMENTS}

Research supported by Fundação de Amparo à Pesquisa do Estado de São Paulo 
(FAPESP \#2006/57514-2), FAPEMIG (Rede Mineira de Ensaios Toxicológicos e Farmacológicos de Produtos Terapêuticos, EDT \#1879/02) and CNPq (\#306544/2006-7).

\section{REFERENCES}

Andraws R, Chawla P and Brown DL (2005). Cardiovascular effects of ephedra alkaloids: a comprehensive review. Prog. Cardiovasc. Dis. 47: 217-225.

Ernst E (2002). The risk-benefit profile of commonly used herbal therapies: Ginkgo, St. John's Wort, Ginseng, Echinacea, Saw Palmetto, and Kava. Ann. Intern. Med. 136: 42-53.

Fukuda M, Ohkoshi E, Makino M and Fujimoto Y (2006). Studies on the constituents of the leaves of Baccharis dracunculifolia (Asteraceae) and their cytotoxic activity. Chem. Pharm. Bull. 54: 1465-1468.

Hartmann A and Speit G (1997). The contribution of cytotoxicity to DNA - effects in the single cell gel test (comet assay). Toxicol. Lett. 90: 183-188.

Heddle JA, Cimino MC, Hayashi M, Romagna F, et al. (1991). Micronuclei as an index of cytogenetic damage: past, present, and future. Environ. Mol. Mutagen. 18: 277-291.

Klaude M, Eriksson S, Nygren J and Ahnstrom G (1996). The comet assay: mechanisms and technical considerations. Mutat. Res. 363: 89-96.

Lemos M, de Barros MP, Sousa JP, da Silva Filho AA, et al. (2007). Baccharis dracunculifolia, the main botanical source of Brazilian green propolis, displays antiulcer activity. J. Pharm. Pharmacol. 59: 603-608.

Lewith GT (2000). Complementary and alternative medicine: an educational, attitudinal and research challenge. Med. J. Aust. 172: 102-103.

Lima ROA (2007). Mecanismos de ação da própolis na modulação de danos quimicamente induzidos no DNA. Doctoral thesis, Universidade Estadual Paulista “Júlio de Mesquita Filho" (UNESP), Botucatu.

MacGregor JT, Wehr CM and Gould DH (1980). Clastogen-induced micronuclei in peripheral blood erythrocytes: the basis of an improved micronucleus test. Environ. Mutagen. 2: 509-514.

Massignani JJ, Lemos M, Maistro EL, Schapauser HP, et al. (2008). Antiulcerogenic activity of the essential oil of Baccharis dracunculifolia on different experimental models in rats. Phytother. Res. (in press).

Menezes H (2005). Avaliação da atividade antinflamatória do extrato aquoso de Baccharis dracunculifolia (Asteraceae). Arq. Inst. Biol. São Paulo 72: 1-64.

Mitchell I and Combes R (1997). In Vitro Genotoxicity and Cell Transformation Assessment. In: In Vitro Methods in Pharmaceutical Research (Castell JV and Gómez-Lechón MJ, eds.). Academic Press, London, 318-352.

Munari CC, Resende FA, Alves JM, de Sousa JP, et al. (2008). Mutagenicity and antimutagenicity of Baccharis dracunculifolia extract in chromosomal aberration assays in Chinese hamster ovary cells. Planta Med. 74: 1363-1367.

Park YK, Paredes-Guzman JF, Aguiar CL, Alencar SM, et al. (2004). Chemical constituents in Baccharis dracunculifolia as the main botanical origin of southeastern Brazilian propolis. J. Agric. Food Chem. 52: 1100-1103.

Pereira AD, de Andrade SF, de Oliveira Swerts MS and Maistro EL (2008). First in vivo evaluation of the mutagenic effect of Brazilian green propolis by comet assay and micronucleus test. Food Chem. Toxicol. 46: 2580-2584.

Resende FA, Alves JM, Munari CC, Senedese JM, et al. (2007). Inhibition of doxorubicin-induced mutagenicity by Baccharis dracunculifolia. Mutat. Res. 643: 112-118.

Salamone M, Heddle J, Stuart E and Katz M (1980). Towards an improved micronucleus test: studies on 3 model agents, mitomycin C, cyclophosphamide and dimethylbenzanthracene. Mutat. Res. 74: 347-356.

Sanchez-Lamar A, Fuentes JL, Fonseca G, Capiro N, et al. (2002). Assessment of the potential genotoxic risk of Phyllantus orbicularis HBK aqueous extract using in vitro and in vivo assays. Toxicol. Lett. 136: 87-96.

Singh NP, McCoy MT, Tice RR and Schneider EL (1988). A simple technique for quantitation of low levels of DNA damage in individual cells. Exp. Cell Res. 175: 184-191.

Sokal RR and Rohlf FJ (1995). The Principles and Practice of Statistics in Biology Research. In: Biometry. W.H. Freeman and Company, San Francisco, 175-205-404-486.

Speit G and Hartmann A (1999). The Comet Assay (Single-cell Gel Test). In: Methods in Molecular Biology, Vol. 113, DNA Repair Protocols: Eukaryotic Systems (Henderson DS, ed.). Humana Press Inc., Totowa, 203-212.

Tavares DC, Mazzaron Barcelos GR, Silva LF, Chacon Tonin CC, et al. (2006). Propolis-induced genotoxicity and antigenotoxicity in Chinese hamster ovary cells. Toxicol. In Vitro 20: 1154-1158.

Tice RR, Agurell E, Anderson D, Burlinson B, et al. (2000). Single cell gel/comet assay: guidelines for in vitro and in vivo genetic toxicology testing. Environ. Mol. Mutagen. 35: 206-221. 